\title{
A NEW AREA OF ALKALINE ROCKS IN EASTERN PARAGUAY
}

\author{
FIERO COMIN-CfflARAMONn*, CELSO B. GOMES**, RICCARDO PETRINI***, Â NGELO DE MIN***, \\ VICTOR E VELAZQUEZ $* * * * *$ and DELIO ORUÉ $* * * * *$
}

INTRODUCTION Alkaline rocks can be found in three major areas (northern, northeastern and central-eastern) of Eastern Paraguay. On die basis of geographic distribution and tectonic association, Livieres \& Quade (1987) proposed inclusion of these outcrop areas different alkaline provinces: Alto Paraguay, Amambay and Central, respectively (Fig. 1). Presently, only the Central Province, clustering the largest number of occurrences, is the subject of systematic investigation. Available information on the Alto Paraguay and Amambay rocks is still scarce.

The western side of the Central Paraná Basin was the site of widespread magmatic activity from Early Cretaceous to Oligocene times in a region that experienced NE-SW trending crustal extension during the late Mesozoic (Comin-Chiaramont et al. 1992, and therein references). Faulting formed a complex NW-trending graben, 25 - $45 \mathrm{~km}$ wide and $200 \mathrm{~km}$ long, in the Asuncion-Sapucai region (Degraff 1985), in which alkaline rocks occurring as dykes, volcanic domes, lava flows, shallow intrusive complexes and stocks cut or rest unconformably on Silurian and Mesozoic sandstones of the Caacupé Group and Misiones Formation, respectively. The region comprises Mesozoic tholeiitic volcanics of the Serra Geral Fomiation (130 $\mathrm{Ma})$ on eastern side, K-alkaline rock-types (128 Ma) in central areas and Tertiary (61 - $39 \mathrm{Ma})$ ultra-alkaline (sodic) rocks on western side (Cormn-Chiaramonti ef al. 1991). •

In the Asuncion-Sapucai graben, K-alkaline rock-types are represented by two suites, i.e. tephrites to phonolites (and peralkaline phonolites) and alkali basalts to trachyphonolites; Na-alkaline rock-types include nephelinites (subofdinately ankaratrites) bearing mantle xenoliths (Demarchi et al. 1986) and. peralkaline phonolites.

Recently, during a field trip to study alkaline magmatism in Eastern Paraguay, alkaline rock-types, i.e. Na-nephelinites with and without mantle xenoliths and K-peralkaline phonolites were found near San Juan Bautista in Southern Paraguay (Fig. 2). The outcrops are associated with red sandstones of the Misiones Formation (Proyecto PAR 83/005, 1986) and show the following characteristics:

Estância Guavira-y $\left(26^{\circ} 57.7^{\prime} \mathrm{S}, 57^{\circ} 06.7^{\prime} \mathrm{W}\right)$. Very small plug, $10 \mathrm{~m}$ high, of Na-nephelinitic rock-types having mantle xenoliths ind addition to clinopyroxene and orthopyroxene megacrysts.

Estância Ramirez $\left(26^{\circ} 56.5^{\prime} \mathrm{S}, 5^{\circ} 10.0^{\prime} \mathrm{W}\right)$. NW-trending Na-nephelinitic dyke, 10 m.thick.

Cerro Caá Jhovy $\left(26^{\circ} 43.2^{\prime} \mathrm{S}, 57^{\circ} 18.3^{\prime} \mathrm{W}\right)$. Small plug, $45 \mathrm{~m}$ high with an area of about $0.8 \mathrm{Km}^{2}$, of K-peralkaline phonolite.

This short paper correlates these new occurrences with the Tertiary Na-rich and Mesozoic K-rich rocks of the Central Province.
PETROGRAPHIC
AND
GEOCHEMICAL
DATA Major and trace element contents of whole rocks were determined by X-ray fluorescence techniques (Bellieni et al 1983); microprobe mineral compositions were analyzed according to Comin-Chiaramonti et al. (1986) and Sm-Nd isotope compositions following the procedures of Comin-Chia-

ramonti et u\& (1991). Representative compositions (whole rocks and mineral phase) are listed in tables 1 to 5.

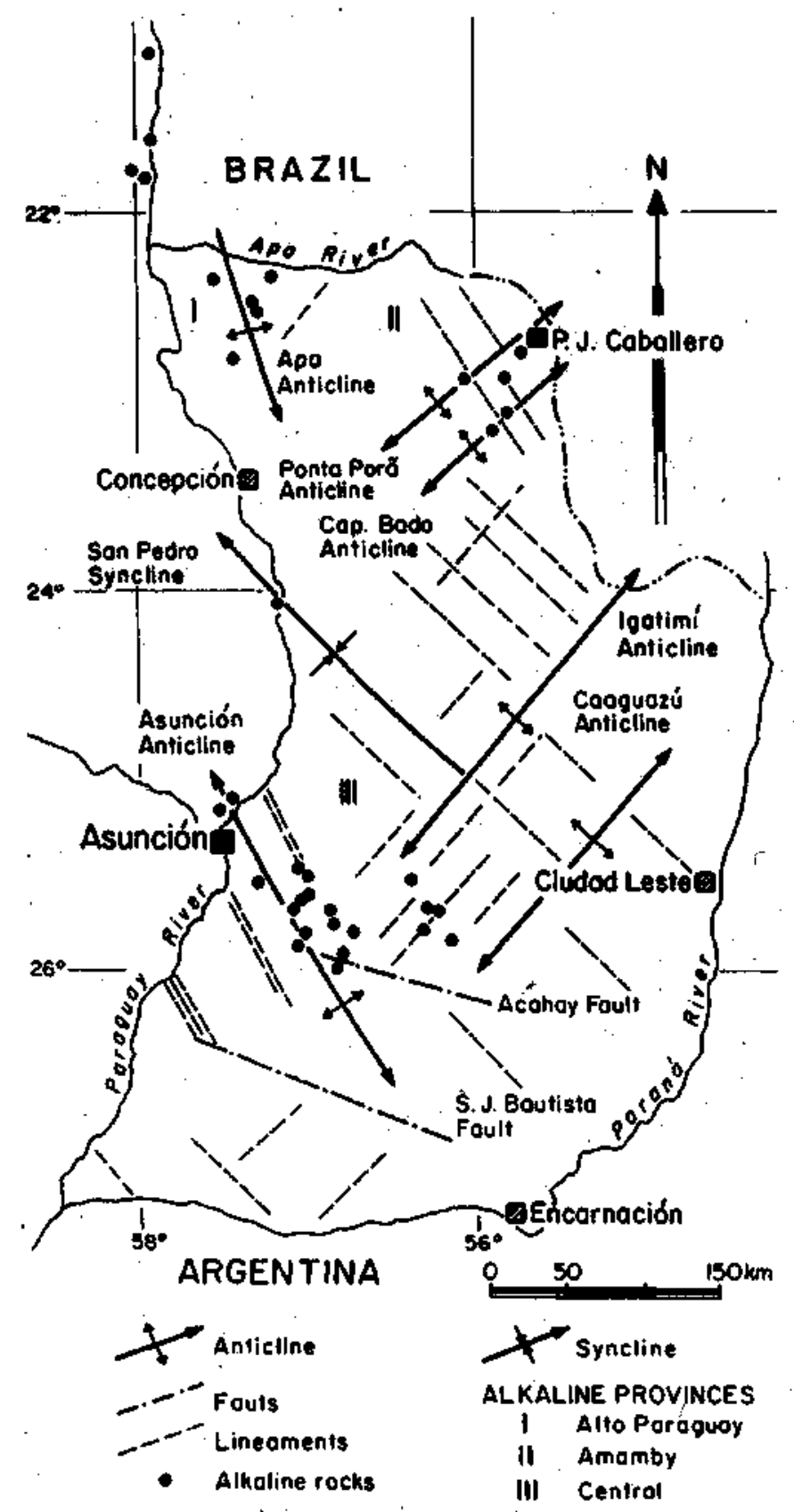

Figure 1 - General distribution of alkaline rocks of Paraguay (after Livieres \& Quade 1987)

Figura 1 - Distribuição geral das rochas alcalinas do Paraguai segundo Livieres \& Quade (1987)

\footnotetext{
* Istítuto dí Mineralogia,Petrografia e Geochimica,Università di Palermo, Italia

** Instituto de Geociências, Universidade de São Paulo, Brasil

*** Istituto di Mineralogia e Petrografia, Universitá di Trieste, Italia

**** Cimo de Pós-Graduação, Instituto de Geociências, Universidade de São Paulo, Brasil

***** Facultad de Ciencias Exactas y Naturales, Universidad Nacional de Asuncion, Paraguay
} 
Table1l - Representative whol rock analyses (major elements in wt\%, trace elements inppm) and isotopic data of rock-types from Southern Paraguay. Glass composition 9G) and calculated intergranular material $(I G)$ from PS-569 renolith (\%); $\mathrm{mg}=\mathrm{Mg} /(\mathrm{Mg}+$ $\mathrm{Fe} 2+$ ), assuming $\mathrm{Fe}_{2} \mathrm{O}_{3} / \mathrm{FeO}$ ratio $=0,20 ; \mathrm{A} \cdot \mathrm{L}-\left(\mathrm{Na}_{2} \mathrm{O}+\mathrm{K}_{2} \mathrm{O}\right) / \mathrm{Al}_{2} \mathrm{O}_{3}$ molar rath $)$

Tabela 1 - Análises representativas de rocha total (elementos nutates em \% em peso, elementos traço em ppm) e dados isotópicos de tipos litológicos do sudeste do Paraguai. Composição do vidro (G) e material intergranular (IG) calculado do xenólito (PS-569); $\mathbf{m g}=\mathbf{M g} /(\mathrm{Mg}+\mathrm{Fe}+$ ), assumindo razão FeA/FeO = 0,20; LA. $=\left(\mathrm{Na}_{2} \mathrm{O}+\mathrm{K}_{2} \mathrm{O} 1 / \mathrm{Al}_{2} \mathrm{O}_{3}\right.$ razão molar $)$

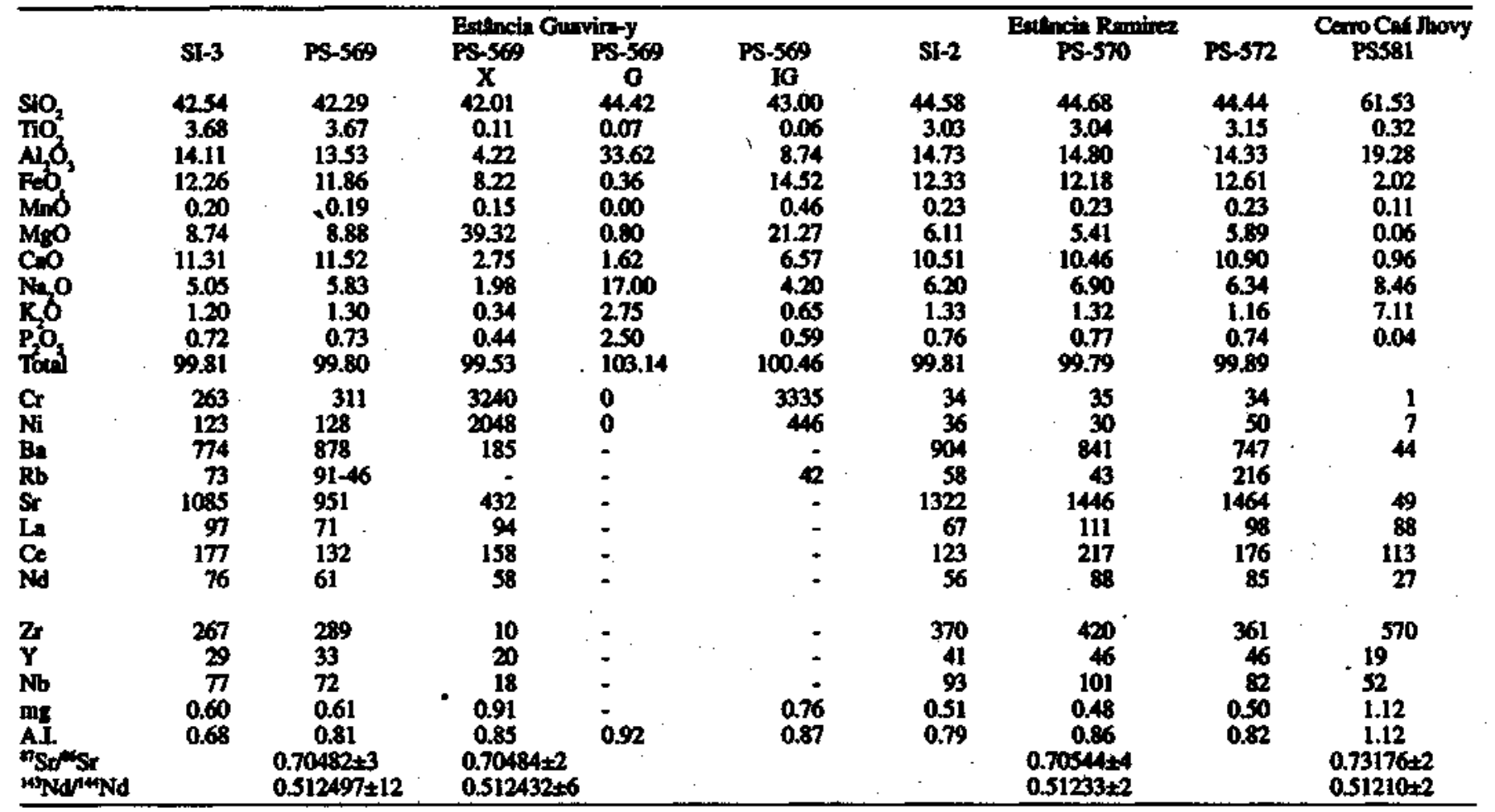

Estância Guavira-y The investigated rock-types are nephelinites, according to the scheme of De La Roche et al. (1980), with $\mathrm{mg}$ values $\left[\mathrm{mg}=\mathrm{Mg} /\left(\mathrm{Mg}+\mathrm{Fe}^{2+}\right)\right.$, assuming $\mathrm{Fe}_{2} \mathrm{O}_{3}$ $\mathrm{FeO}=0.20]$ ranging from 0.60 to 0.61 . Texture is typically porphyritic with clinopyroxene olivine phenocrysts/ microphenpcrysts set in a hypocrytalline groundmass made up of glass, clinopyroxene, olivine, opaques and. foids.

Clinopyroxene and orthopyroxene megacrysts (not studied in this work), varying in size from a few $\mathrm{mm}$ to $10 \mathrm{~cm}$, are widespread and occur in association with mantle xenoüths. These correspond to dunites with olivine and interstitial chromiferous spinel, largely infilled by glassy patches containing clinopyroxene and olivine microlites.

In the host nephelinites olivine phenocrysts/ microphenocrysts have mg ranging from 0.83 to 0.80 (in equilibrium with a liquidus with $\mathrm{mg}$ of 0.62 to 0.57 , roughly corresponding to the mg of the whole rock; $\mathrm{cf}$. Tab. 1), whereas olivine microlites show $\mathrm{mg}$ around 0.78 . It should be noted that analogous olivine from the Assunción nephelinites (Comin-Chiaramonti et al. 1991) present $m g$ values of 0.89-0.85 (phenocrysts), 0.82-0.77 (microphenocrysts) and 0.76-0.74 (groundmass).

$\mathrm{Mg}$ of clonopyroxene phenocrysts to microlites varies from 0.87 to 0.81 ; on the other hand, the $m g$ range for clinopyroxene from the Asuncion nephelinites is $0.80-0.75$. The opaques are titanian - magnetite ( 64 mole $\%$ ulvospinel), similar to those of the Asuncion rocks (60-65 mole \% ulvospinel). Foids are nepheline $(6 \% \mathrm{Q}, 76 \% \mathrm{Ne}, 18 \% \mathrm{Kp}$, in wt), showing no stoichiometry; groundmass foids of Asuncion nephelinites are almost stoichiometric with $84 \% \mathrm{Ne}$ and $16 \% \mathrm{Kp}$ (CominChiaramonti et al. 1991).

The xenoliths have olivine of the dunitic assemblage with $\mathrm{mg}$ of 0.90 and spinel with $\mathrm{Cr} /(\mathrm{Cr}+\mathrm{Al})=0.21$ (atomic ratio); the olivine-spinel geothermometer (Fabries 1979) indicates a temperature of $944^{\circ} \mathrm{C}$, reflecting subsolidus re-equilibration.

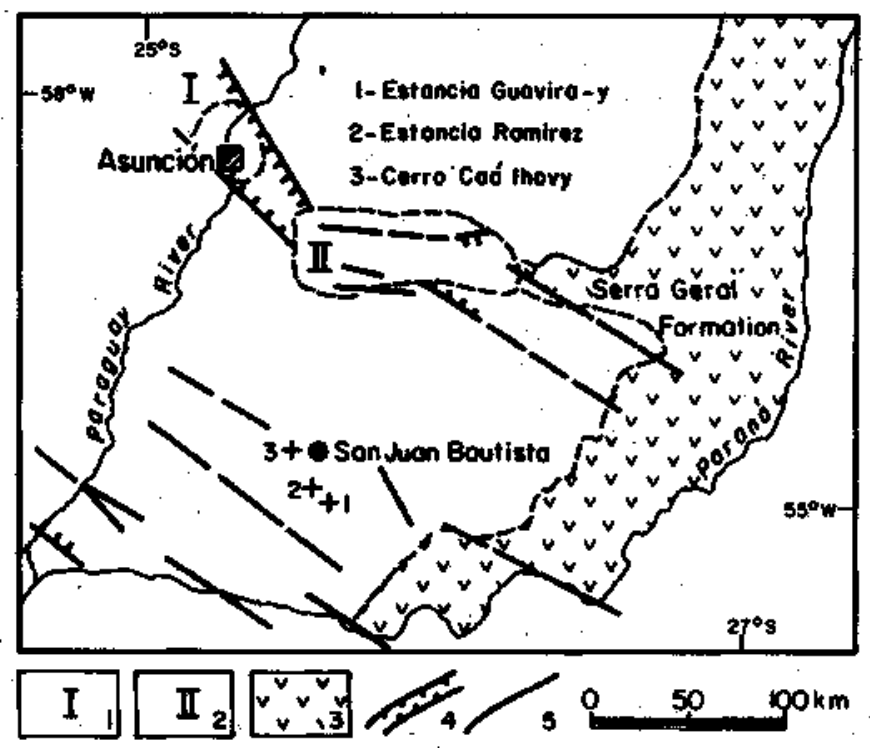

Figure 2 - Rifle tectonics and alkaline magmatism of centraleastern Paraguay (after Degraff 1985, Comin-Chiaramonti et al. 1992). Also shown are ike alkaline occurrences near San Juan Bautista. Legendas: 1. Tertiary Na-alkaline rocks; 2. Mesozoic K-alkaline rocks; 3. Mesozoic tholeiitic basalts; 4. Asuncion-Sapucai rift; 5. Faults

Figura 2 - Tectômica de rifle e magmatísmo alcalino da porção centrooríental do Paraguai (segundo Degraff 1985, Comin-Chiaramonti et al. 1992). Mostram-se também as ocorrências alcalinas próximas à cidade de San Juan Bautista. Legendas: 1. Rochas akalinas sódicas terciánas; 2. Rochas alcalinas potássicas mesozóicas; 3. Basaltos tolétos mesozóicos; 4. Rifte AssunçãoSapucai; 5. Falhas 
Table 2 - Representative analyses ofolivine. $\boldsymbol{P}=$ phenocrysts $($ c-core, $r$-rim $) ; \boldsymbol{m} \boldsymbol{P}=$ microphenocrysts; $\boldsymbol{m}=$ groundmass phases; $\boldsymbol{M}$ - crystals oftheperidotitic assemblage; $\boldsymbol{I} \boldsymbol{G}$ - microcrystals in the glassy patches of mantle xenoliths, Crystallochemical formula on 4(0) basis

Tabela 2 - Análises representativas de olivina. $\mathbf{P}=$ fenocristais (c-núcleo, $r$-borda); $\mathbf{m P}=$ microfenocristais; $\mathbf{m}=$ fases da massa fundamental; $\mathbf{M}=$ cristais da associação peridotítica; IG = microcristais na massa vítrea dos xenólitos mantélicos. Fórmula cristaloquímica na base de 4 (0)

\begin{tabular}{|c|c|c|c|c|c|c|c|c|}
\hline & & & & Guavira- & & & Eston & Zaminez \\
\hline & & Nephelit & 569 & & Xeno & $569 x$ & Nephel: & PS-570 \\
\hline & $\mathbf{P c}$ & Pr & $\mathrm{mP}$ & m & $\mathbf{M}$ & is & mP & 血 \\
\hline $\mathrm{SiO}_{2}^{-}$ & 39.84 & 39.74 & 39.28 & 38,49 & 41.35 & 40,50 & 36.60 & 37,60 \\
\hline $\mathrm{FeO}$ & 16.41 & 18.83 & 19.00 & 20.13 & 9.39 & 11,68 & 23,48 & 26.65 \\
\hline Mro & 0.12 & 0.20 & 0.40 & 0.45 & 0.22 & 0,32 & 0.54 & 0.90 \\
\hline NiO & 0.15 & 0.20 & 0.16 & 0.13 & 0.39 & 0.26 & 0.08 & 0.05 \\
\hline $\mathrm{M}_{\mathrm{g}} \mathrm{O}$ & 43.96 & 42.36 & 41.60 & 40.47 & 49.87 & 47.11 & 38.15 & 34.49 \\
\hline $\mathrm{COO}$ & 0.20 & 0.25 & 0.20 & 0.34 & 0.02 & $0.5 t$ & 0.37 & 0.59 \\
\hline Total & 100.68 & 10158 & 100.64 & 100.66 & 101.24 & 100.38 & 101.19 & 100.28 \\
\hline Si & 1.000 & 1.000 & 1.000 & 0,999 & 1.000 & 1.000 & 0.999 & 1.000 \\
\hline $\mathrm{Fe}^{2+}$ & 0.344 & 0.396 & 0.404 & 0.435 & 0.190 & 0.241 & 0.507 & 0.593 \\
\hline Mn & 0.003 & 0.004 & 0.009 & 0.010 & 0.004 & 0.007 & 0.012 & 0.000 \\
\hline $\mathbf{N i}$ & 0.003 & 0.004 & 0.003 & 0.003 & 0.008 & 0.005 & 0.002 & 0.001 \\
\hline $\mathrm{Mg}$ & 1.644 & 1.589 & 1,578 & 1.557 & 1.797 & 1.734 & 1.471 & 0.698 \\
\hline $\mathrm{Cl}$ & 0.005 & 0,007 & 0.005 & 0.009 & 0.001 & 0.013 & 0.010 & 0.017 \\
\hline Total & 2999 & 3,000 & 2.999 & 3.007 & 3.000 & 3.000 & 3.001 & 2.999 \\
\hline $\mathrm{mg}$ & 0.83 & 0.80 & 0.80 & 0.78 & 0.90 & 0.88 & 0.74 & 0.70 \\
\hline
\end{tabular}

Table 3 - Representative analyses of clinopywxenes. Symbols and letters as in table 2. Crystallochemical formula on 6 (O) basis; $\mathrm{Fe}_{2} \mathrm{O}_{3}$ and $\mathrm{FeO}$ recalculated by stoichiometry

Tabela 3 - Análises representativas de clinopiroxênios. Símbolos e letras na tabela 2. Fórmula cristaloquímica na base de 6 (0); $\mathrm{Fe}_{2} \mathrm{O}_{3}$ e $\mathrm{FeO}_{\mathrm{O}}$ recalculados por estequiometria.

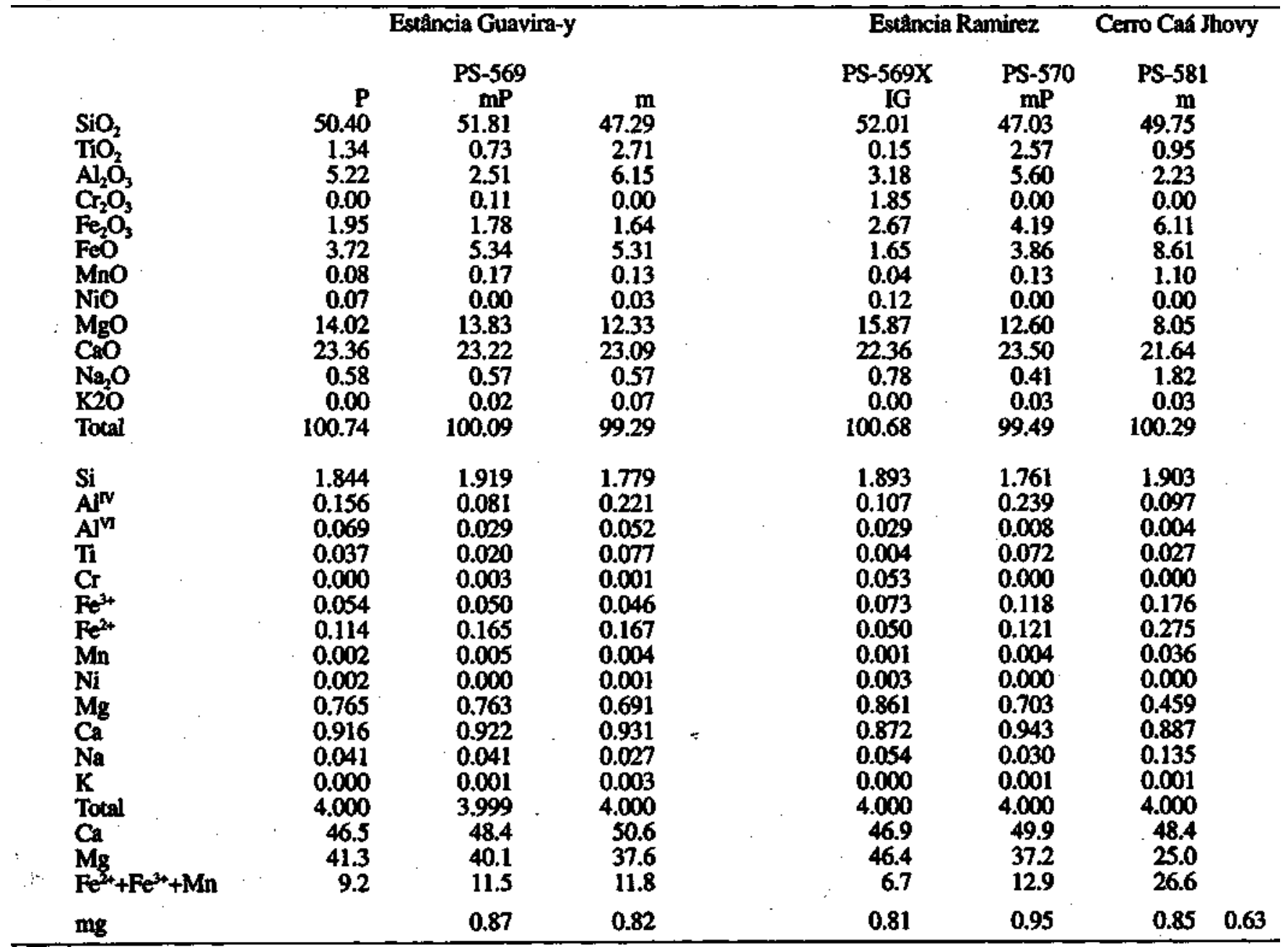


Table 4 - Representative analyses of opaques. Symbols and letters as in table 2. Crystalhchemical formula on 4 (O) basis; Fe2O3 recalculated on ulvospinel basis

Tabela 4 - Análises representativas de opacos. Símbolos e letras como na tabela 2. Fórmula cristaloquímica na base de 4 (O); Fe2O3 e FeO recalculados na base de ulvoespinélio

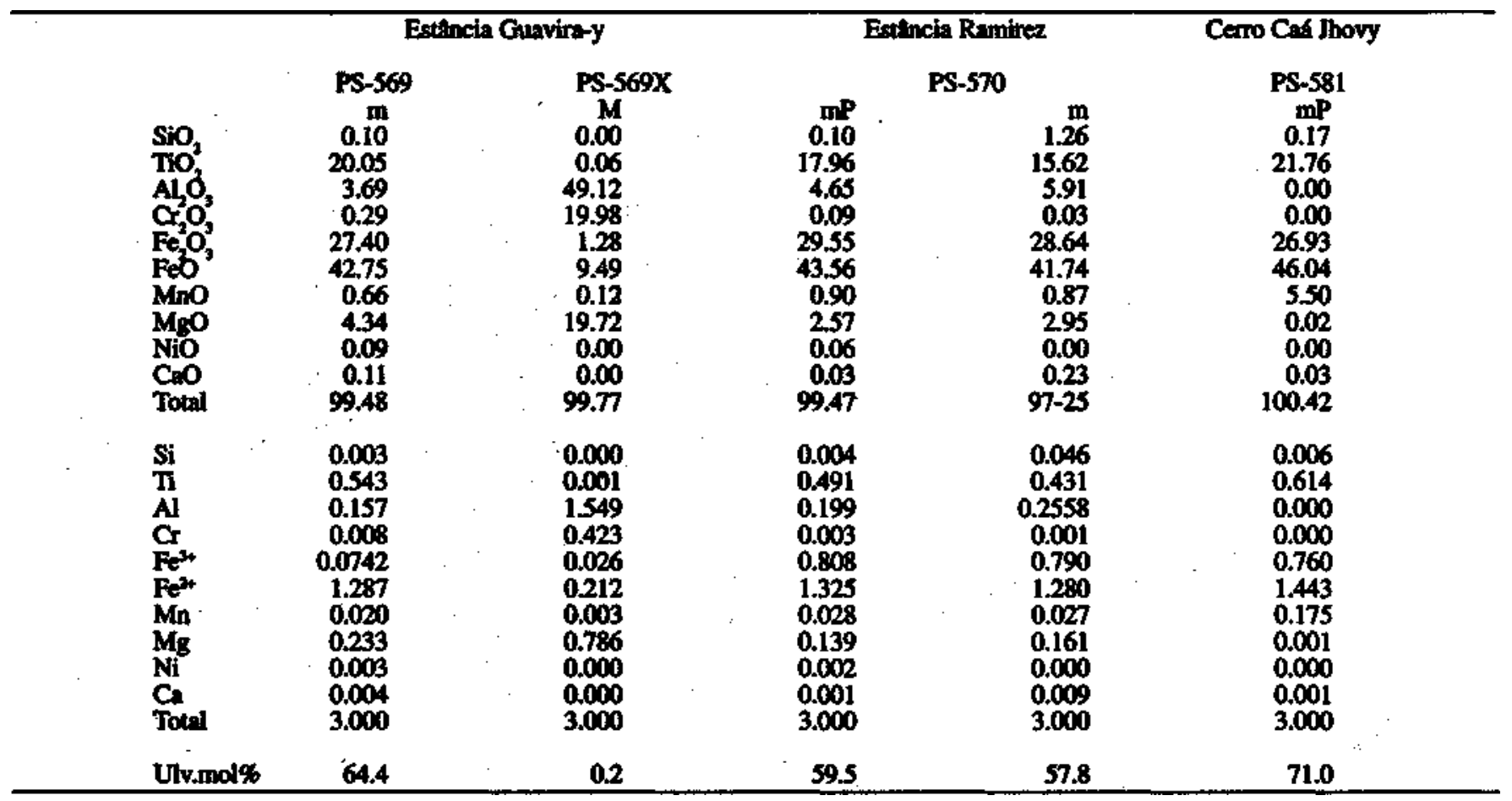

Olivine and clinopyroxene microlites from the glassy patches have $\mathrm{mg}$ of 0.88 and 0.95 , respectively.

Mass balance calculations for the xenoliths reveal that they are composed $(\Sigma \mathrm{R} 2=0.041-0.015)$ of $56.7 \%$ of peridotitic assemblage $(55.8 \% \mathrm{Ol}+0.95 \mathrm{Sp})$ and of $43.7 \%$ of intergranular material $(21.9 \% \mathrm{Ol}, 11.5 \% \mathrm{Cpx}$ and $10.3 \%$ glass $)$.

Assuming that the infilled material is representative to some extent of a primary liquid, the calculated liquid $(21.9 \% \mathrm{Ol}$, $11.5 \% \mathrm{Cpx}, 10.3 \%$ glass) has mg of 0.76 , corresponding, in equilibrium conditions, to an olivine with $m g$ of 0.91 , this being a value similar to that of the peridotitic assemblage. But, in this case, the olivine microlites are not in equilibrium with such a liquid, and it is believed that they represent the product of a mor evolved liquid, having presumably $\mathrm{Cpx}$ as the first crystallizing phase. Moreover, die mass balance $(2 \mathrm{R} 2>>1)$ shows clearly that the host nephelinites cannot be derived from the calculated liquid. On the whole, the mantle xenoliths from Estância Guavira-y are quite different respect to the Asuncion nephelinitex, which show Ol-Opx-Cpx-Sp assemblages grading from dunites to Iherzolites (Demarchi et al 1986).

Estância Ramirez The sampled rocks are nephelinites with $\mathrm{mg}$ in the range of $0.51-0.48$. Texture is porphyritic with clinopyroxene $(m g=0.85)$, olivine $(m g=0.74)$ and Timagnetite ( 59.5 mole \% ulvospinel) microphenocrysts set in a hypohyaline groundmass consisting of otivine $(\mathrm{mg}=0.70)$, opaques (57.8 mole \% ulvospinel) and foids $(15 \% \mathrm{Q}, 73 \% \mathrm{Ne}$, $12 \% \mathrm{Kp}$, in wt) microlites. The relatively low $\mathrm{mg}$ value in addition to the low $\mathrm{Cr}$ and $\mathrm{Ni}$ contents (cf. Tab. 1) indicate that Estância Ramirez nephelinitres represent a derivative magma. Mass balance (major elements) calculations show the impossibility of deriving this rock-type from the Estância Guavira-y nephelinites through fractional crystallization (RR2 $=0.71$ ), a process requiring the extraction of olivine $(6 \%)$, clinopyroxene $(27 \%)$, nepheline $(17 \%)$, titanian-magnetite $(6 \%)$ and apatite $(1 \%)$. Additionally, the incompatible trace element calculated/observed ratios (Rayleigh fractionation; partition coefficients after Bristow 1984) display a random range between 0.6 and 2.4, suggesting the existence of an independent parental magma.

Thus, geochemical evidence points to distinctive forerunners for the San Juan Bautista nephelinites. Moreover, the mineral chemistry exhibits different features respecto to the Asuncion nephelinites. As a matter of fact, if comparison is made on the basis of major and trace elements, the San Juan Bautista nephelinites are characterized by lower $\mathrm{SiO}_{2}, \mathrm{Al}_{2} \mathrm{O}_{3}, \mathrm{P}_{2} \mathrm{O}_{5}, \mathrm{Cr}$, $\mathrm{Ni}, \mathrm{Ba}, \mathrm{Nb}$ and higher $\mathrm{TiO}_{2}$ FeOt and Rb contents (Fig. 3).

Cerro Caá Jhovy The peralkaline phonolite is porphyritic with alkali feldspar phenocrysts (44\% Or, 55\% Ab, in wt) and opaques microphenocrysts ( 71 mole $\%$ ulvospinel) set in a glassy matrix of clinopyroxene (10\% acmitic component) and feldspar microlites $(45 \%$ Or, $54 \% \mathrm{Ab}$, in wt). Five chemical analyses of samples collected at different levels of the plug (P. CominChiaramonti, unpublished data) indicate that the outcrop is very homogeneous, die variations falling within the limits of the analytical error.

The $\mathrm{K}_{2} \mathrm{O} / \mathrm{Na}_{2} \mathrm{O}$ (wt) ratio is 0.84 and lies in the main range for the K-alkaline rock-types of the Asunción-Sapucai graben (0.6-4.0: Comin-Chiaramonti et al. 1992). Main differences with respect to these rocks deal with the lower $\mathrm{Al}_{2} \mathrm{O}_{3}, \mathrm{Sr}$ and $\mathrm{Zr}$ and higher $\mathrm{TiO}_{2}, \mathrm{~K}_{2} \mathrm{O}$ and $\mathrm{Rb}$ contents of the Cerro Caá Jhovy phonolite (Fig. 4).

Sr and Nd isotopes Preliminary data show that "Sr/ "Sr ratios for the host nephelinite and mantle xenoliths from Estância Guavira-y are 0.70482 \pm 3 and $0.70484 \pm 2$, respectively (Tab. 1). Regarding the latter the isotopic ratio probably reflects the contribution of the infilled glassy material, indicating that the source for both host nephelinite and infilled material is isotopically the same.

Quite different is the isotopic ratio for the Estância Ramirez outcrop, ${ }^{87} \mathrm{Sr} /{ }^{86} \mathrm{Sr}=0.70544 \pm 4$. Qn the other hand, the CerroCaa Jhovy plug displays a very high ${ }^{87} \mathrm{Sr} /{ }^{86} \mathrm{Sr}$ ratio of $0.73176 \pm 2$. 


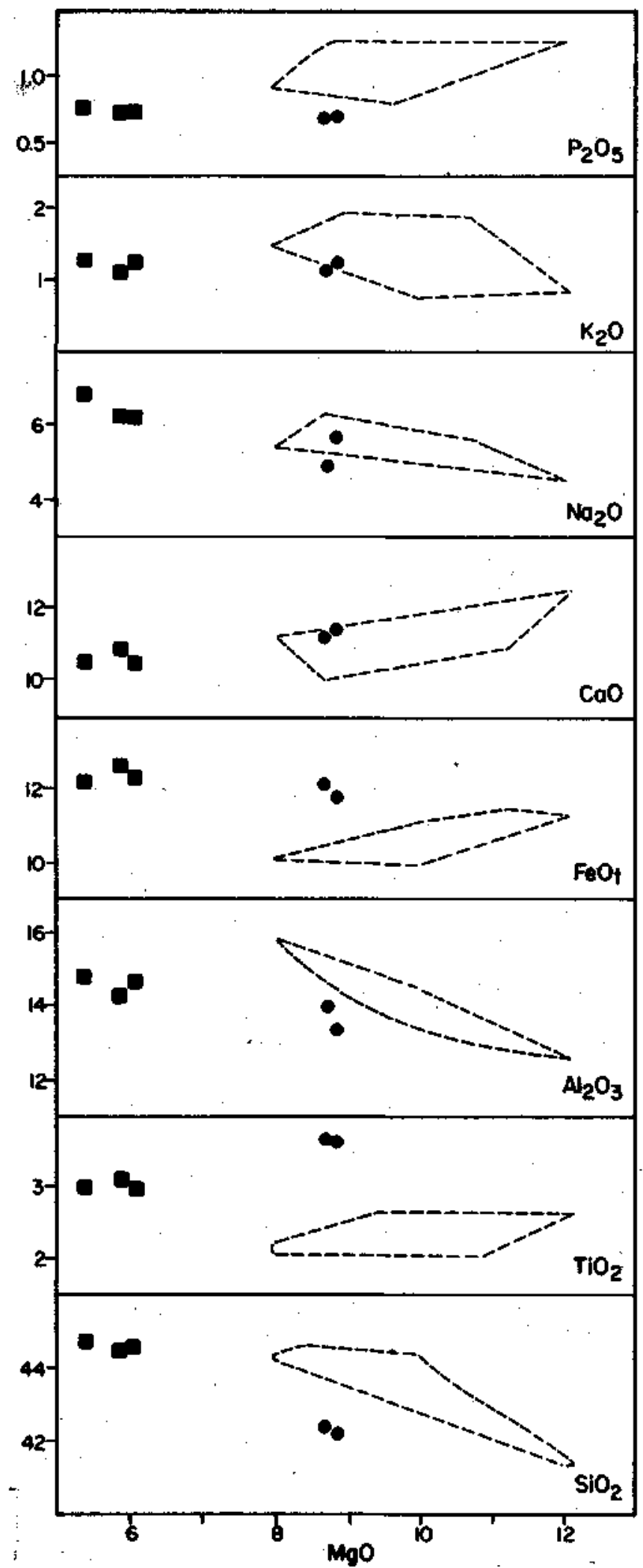

Figure 3 - $\mathrm{MgO}$ (wt\%) vs. (a) major (wt\%) and (b) trace element (ppm) diagrams for the nephelinites of the San Juan Bautista area. Dots, Estância Guavira-y; squares, Estância Ramirez; outlined area represents the field of the Asuncion nephelinites (Comin-Chiaramontietal. 1991) Figura 3 - Diagramas de vai ição $\mathrm{MgO}$ (\% em peso) vs. (a) elementos maiores (\% em peso) e (b) traços ppm) para os nefelinitos da área de San Juan Bauüsta. Círculos, Estância Guavira-y; quadrados, Estância Ramirez; área assinalada representa o campo dos nefelinitos de Assunção (CominChiaramonti et al. 1991)
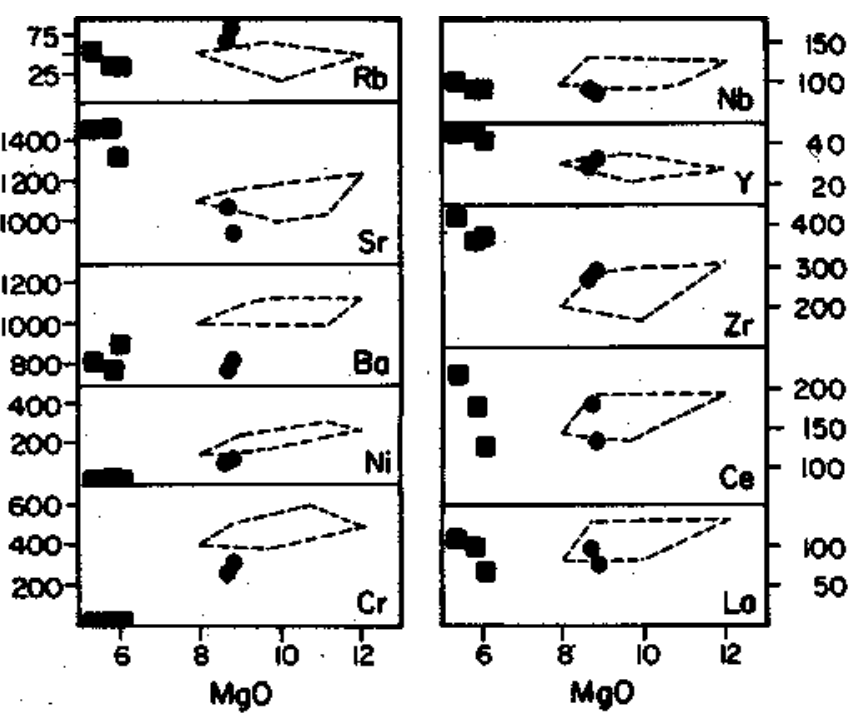

Table 5 - Representative analyses of folds (PS-569 and PS-570) and alkali feldspars (Ps-581). Symbols and letters an in table 2. Crystallochemical formula on 8 basis Tabela 5 - Análises representativas de fóides (PS-569 e PS-570) e fedspatos alcalinos (PS-581). Símbolos e letras como na tabela 2. Fórmula cristaloquímica na base de $8(0)$

\begin{tabular}{|c|c|c|c|c|}
\hline & \multirow{2}{*}{$\begin{array}{c}\text { Estancia } \\
\text { Guavira-y } \\
\text { PS-569 } \\
\text { m }\end{array}$} & \multirow{2}{*}{$\begin{array}{r}\text { Estincia } \\
\text { Ramirez } \\
\text { PS-570 } \\
\mathbf{m}\end{array}$} & \multicolumn{2}{|c|}{$\begin{array}{c}\text { Cerro } \\
\text { CaA Jhovy } \\
\text { PS-581 }\end{array}$} \\
\hline & & & $\mathbf{P}$ & m \\
\hline $\mathrm{SiO}_{2}$ & 44.16 & 47.78 & 66.73 & 66.19 \\
\hline $\mathrm{Al}_{2} \dot{\mathrm{O}}_{3}$ & 33,68 & 31.50 & 18.91 & 18.73 \\
\hline $\mathrm{Fe}_{2} \mathrm{O}_{3}$ & 1.38 & 0.77 & 0.19 & 134 \\
\hline Mno & 0.02 & 0.03 & 0.00 & 0.00 \\
\hline $\mathrm{CnO}$ & 1.71 & 1.01 & 0.08 & 0.19 \\
\hline BAO & 0.07 & 0.05 & 0.15 & 0.00 \\
\hline $\mathrm{SrO}$ & 0.04 & 0.05 & 0.00 & 0.00 \\
\hline $\mathrm{N}_{2}, \mathrm{O}$ & [4.9] & 14.28 & 6.52 & 6.36 \\
\hline $\mathbf{K}, \dot{\mathbf{O}}$ & 4.86 & 3.27 & 7.45 & 7.52 \\
\hline Tocal & 100.83 & 98.74 & 100.03 & 99.33 \\
\hline Si & 2.092 & 2.259 & 2994 & 2968 \\
\hline Al & 1.881 & 1.756 & 1.000 & 1.021 \\
\hline $\mathrm{Fe}_{\mathbf{E}}$ & 0.049 & 0.027 & 0.006 & 0.012 \\
\hline Mn & 0.001 & 0.001 & 0.000 & 0.000 \\
\hline $\mathrm{Ca}$ & 0.87 & 0.051 & 0.004 & 0.008 \\
\hline Ba & 0.001 & 0.001 & 0.003 & 0.000 \\
\hline sr & 0.001 & 0,001 & 0.000 & 0.000 \\
\hline $\mathrm{Na}$ & 1.369 & 1.309 & 1.567 & 0.570 \\
\hline $\mathbf{K}$ & 0.294 & 0.197 & 0.426 & 0.443 \\
\hline Toxal & 5.775 & 5.629 & 5.000 & 5.022 \\
\hline $\mathbf{Q}$ & 5.8 & 15.2 & & \\
\hline Ne & 76.1 & 72.6 & & \\
\hline $\mathbf{K p}$ & 18.1 & 12.2 & & \\
\hline
\end{tabular}

At The present time, no age data are available for the alkaline rocks of Southwertern Paraguay which could provide initial ${ }^{87} \mathrm{Sr} /{ }^{86} \mathrm{Sr}(\mathrm{RO})$ ratios. But if the relationship between Ro and age (Ma) relative to the Asuncion nephelinites holds true (CominChiaramonti et al. 1991), itwould be possible to derive age values by applying the equations $\{\mathrm{Ro}=0.702904+1.687$ $10-5 \mathrm{Ma}$ and $\left\{\mathrm{Ro}=\left({ }^{87} \mathrm{Sr} /{ }^{86} \mathrm{Sr}\right)_{\text {meas }}-(\mathrm{Rb} / \mathrm{Sr})_{\text {meas }} 4.1110-5 \mathrm{Ma}\right.$, as inferred by those authors, as follows:
PS-569

PS-569X

PS-570

PS581
Age(Ma) Ro
Estância Guavira-y

Estância Guavira-y

Estância Ramirez

Cerro Caá Jhovy 

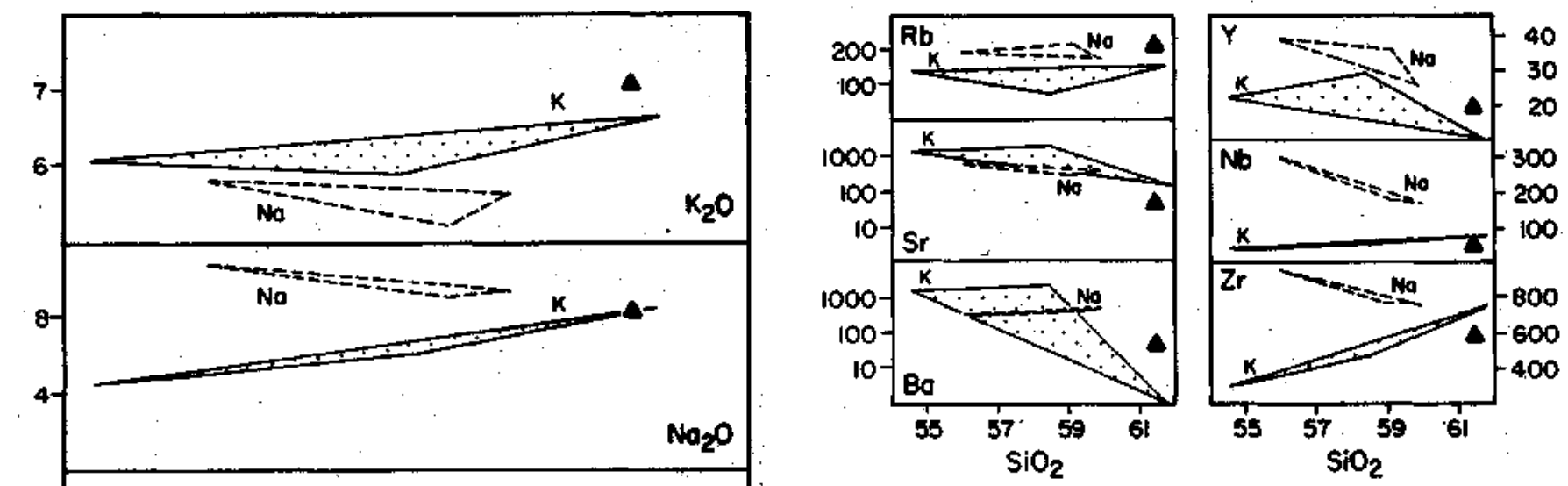

The ${ }^{143} \mathrm{Nd} /{ }^{144} \mathrm{Nd}$ isotopic ratios for Estância Guavira-y host nephelinite and xenoliths, Estância Ramirez nephelinite and Cerro Caá Jhovy phonolite indicate isotopically distinct sources with respect to the other alkaline rock-types of Central-Eastern Paraguay (Fig. 5). For the Cerro Caá Jhovy plug, lying outside the main array for Eastern Paraguay occurrences, a younger age and crustal contamination cannot be disregarded.

FINAL REMARKS The alkaline occurrences of Southern Paraguay exhibit mineralogical, petrochemical and geochemical characteristics which are quite distinctive from those shown by the alkaline rock-types from Central-Eastern Paraguay (i.e. Asunción-Sapucai graben).

If the estimated values for ages can be confirmed, field evidence appear to suggest that taphrogenetic events spanning the entire Early Cretaceous affected an area of Southern Paraguay, parallel to the Asunción-Sapucai graben and also characterized by direct fault (degraff 1985).

Probably another rift structure, also induced by extensional Mesozoic tectonics and lying south of the AsunciónSapucai graben, is present in Southern Paraguay. Other alkaline complexes may occur in association with this structure.

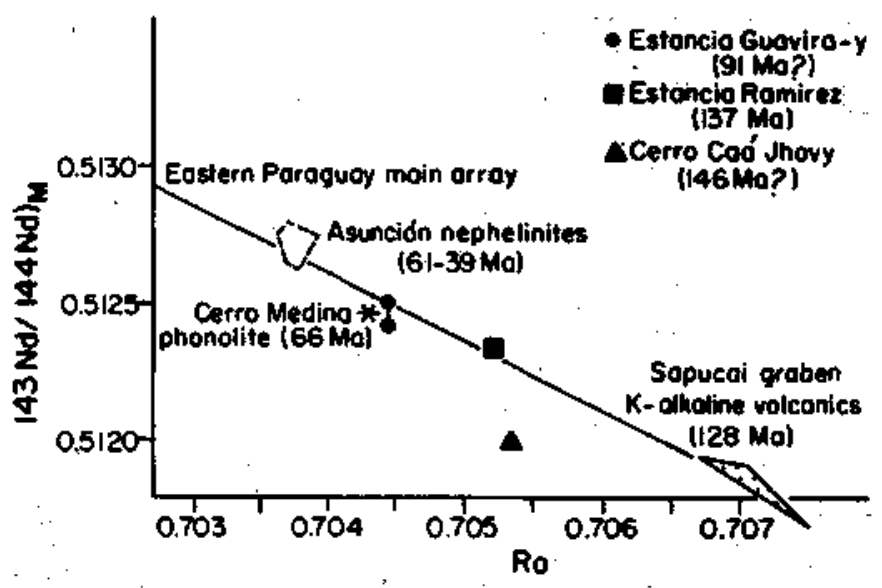

Figure 5-Ro (initial ${ }^{87} \mathrm{Sr}^{86} \mathrm{Sr}$ isotopic ratios) vs. (measured isotopic ratios) for the alkaline occurrences of Eastern Paraguay. Also shown is the mantle array $(n-0.9901)$ for the different rock-types

Figura 5 - Gráfico reunindo Ro (razões isotópicas iniciais ${ }^{87} \mathrm{Sr} / 86 \mathrm{Sr}$ ) e ${ }^{143} \mathrm{Nd} /$ ${ }^{144} \mathrm{Nd}$ (razoes isotópicas medidas) para as ocorrências alcalinas do Paraguai Oriental. O arranjo mantélico $(\mathrm{n}=0,9901)$ para as diferentes litologias alcalinas é também mostrado.
Figure 4-SiO $2(w t \%)$ vs. (a) major (wt\%) and(B) trace element (ppm) diagrams for the Cerro Caá Jhovy phonolite. Also indicated are the fields for K-alkaline (dots) and Na-aJkaline (dashed) rock-types of the Asuncion-Sapucai Graben area Figura 4 - Diagramas de variação $\mathrm{SiO}_{2}(\%$ em peso) vs. (a) elementos maiores (\% em peso) e (b) traços (ppm) para o fonolito do Certo Caá Jhovy. Mostramse também os campos para as litologias alcalinas potássicas e sódicas da área do Graben Assunção-Sapucai 
Detailed studies however will be necessary not only to confirm this hypothesis but also to explore the possibility that mantle xenoliths from the San Juan Bautista and Asuncion areas may be related to different mantle sources.
Acknowledgements Thanks are due to Brazilian (FAPESP, Proc. 90/3692-7) and Italian (MURST) agencies for financial support and also to Prof. Thomas R. Fairchild for reviewing the English.

\section{REFERENCES}

BELUENI, G.: BROTZU. P.; COMTN-CfflARAMONTI, P.; ERNESTO, M.; MELFI, AJ.; PACCA, I.G.; PICCIRILLO, E.M.; STOLFA, D.1983. Petrological and patoomagnetic data on the Plateau basalt to rhyolite sequences of the Southern Paraná Basin (Brazil). An. Acad. bras, dene., 55:355-383.

BRISTOW, J.W. 1984. Nephelinites of the Lebombo and south-east Zimbabwe. Spec. Publ. Geol. s. Afr, 13:87-104.

COMIN-CHIARAMONTI, P · CIVETTA L · PETOINI, R ; PICCIRILLO, EM.; BELLJENI, G.; GENSI, P.; BITSCHENE, P.; DEMARCHI, G.; 1991. Tertiary nephelinitic magmatism in Eastern Paraguay: petrology, $\mathrm{Sr}-\mathrm{Nd}$ isotopes and genetic relationships with associated spinelperidotite xenoliths. EURJ.111: J. Mineral, 3:507-525

COMIN-CHIARAMONTI, P.; CUNDARI, A.; GOMES, C.B.; PICCIRJLLO, E.M.; CENSI, P.; DE MIN. A.; BELUENI, G.; VELAZQUEZ, V.F.; ORUE, D. 1992. Potassic dyke swarm in the Sapucai graben, Eastern Paraguay: petrologkal, mineralogical and geochemical outlines. Lithos, 28:283-3017

COMIN-CHIARAMONTI. P.; DEMARCHI, G.; GIRARDI, V.A.V.; PRINOVALLE, E; SINIGOI, S. 1986. Evidence of mantle metasomatism and heterogeneity from peridotite inclusions of northeastern Brazil and Paraguay. E.RL S., 77:203-217.

DE LA ROCHE, R; LETERRIER, J; GRANDCLAUDE, P.; MARCHAL, M. 1980. A classification of volcanic and plutonic rocks using R1-R2 diagram and major-element analyses. Its relationships with current nomenclature. Chan. GeoL, 29:183-210.
DEGRAFF, I.M. 1985. Late Mesozoic crustal extension and rifting on the western edge of the Paraná basin, Paraguay. Geol. Soc. Amer., 17:560. (Abstract with Programs).

DEMARCHI, G.; COMIN-CHIARAMONTI, P.; DE VTTO, P.; SINIGOI, S.; CASTILLO, C.A.M. 1986. Lherzolite-dunite xenoliths from Eastern Paraguay: petrological constraints to mantle metasomatism. In: PICCIRILLO, E.M. \& MELFI, A.J. eds The Mesozoic Flood Volcanism from the Paraná Basin (Brazil): Petrogenetic and Geophysical Aspects. São Paulo, IAG/USP. p. 207-227.

FABRIÉS, J,. 1979. Spinel-olivine geothermometty in peridotites from ultramafic complexes. Contrib. Mineral. Petrol., 69:329-336.

LJVIERES, R.A. \& QUADE, H. 1987. Distribution regional y asentamiento tectónico de los complejos alcalinos del Paraguay. Zbl GeoL PaJaont. 7/8(TeilI,H):791-805.

PROYECTO PAR 83/005 1986. Mapa Geológico del Paraguay. Asuncion, Comission Nacional de DesarroUo Regional/Ministério de Defensa Nacional. 270 p.
MANUSCRITO NB007

Recebido em 9 de fevereiro de 1992 Revisão em 12 de junho de 1992 